\title{
Molecular Characterization of 25 Mango Germplasm Using RAPD Markers Available in the South-western Region of Bangladesh
}

\author{
M. A. Hossain ${ }^{1 *}$, M. M. Islam ${ }^{1}$, M. A. Mannan ${ }^{1}$, S. K. Roy ${ }^{2}$ and P. Shil ${ }^{3}$ \\ ${ }^{1}$ Agrotechnology Discipline, Khulna University, Khulna (9208), Bangladesh \\ ${ }^{2}$ Agri Studies, Khulna Public College, Boyra, Khulna (9000), Bangladesh \\ ${ }^{3}$ Agri. Studies, Khulna Model College, Boyra, Khulna (9000), Bangladesh
}

\section{Article History}

Manuscript No. AR1629a

Received in $1^{\text {st }}$ July, 2016

Received in revised form $27^{\text {th }}$ July, 2016

Accepted in final form $4^{\text {th }}$ August, 2016

\section{Correspondence to}

"E-mail: asgarkpc29@gmail.com

\section{Keywords}

Mango germplasm, molecular

characterization, genetic diversity

\begin{abstract}
RAPD (Randomly amplified polymorphic DNA) markers were used for the genetic variation and relationship analysis among 25 Mango (Mangifera indica L.) germplasm (Gp). PCR amplification with seven primers generated 48 reproducible, clear and distinct bands, out of which $46(95.92 \%)$ bands are considered polymorphic and the remaining 2 fragments (4.08\%) monomorphic.RAPD matrix of the 25 germplasm of mango using seven primer were assembled for statistical analysis the sizes of the fragments were estimated using DNA $1 \mathrm{~kb}$ and $100 \mathrm{bp}$ ladder by electrophoresis with the PCR products. The average polymorphism in all the 25 cultivars using the seven primers was found to be $95.92 \%$. Among all the primers AL 07, OPO 07, OPK 14, OPG 17 and OPA 06 have shown 100\% polymorphism while OPH 15 and OPF 08 were found to be least polymorphism (85.71\%). The UPGMA (Unweighted Pair Group Method of Arithmetic Mean) dendrogram based on Jaccard's similarity coefficient segregated the 25 mango germplasm into two clusters. The dendrogram shows that all the germplasm were grouped into two major clusters 16 mango germplasm in one groups and rest 9 mango germplasm is another group.The values of pair-wise comparisons of Nei's (1979) genetic distance among 25 mango genotypes were computed from 0.043 to 0.510 . Comparatively the highest genetic distance 0.510 was found between Gp no. 52 (Langra) vs. Gp73 (Hybrid-10). The lowest genetic distance was found between Gp no. 50 (0.043) (Bhut Bomby) and Gp no. 52 (Langra). Results from the given study would be useful breeders for further improvement of mango varieties.
\end{abstract}

\section{Introduction}

Mango (Mangifera indica L.) is a fruit species native to Asia and grown widely in tropical and subtropical countries (Souza et al., 2002). India is the leading mango producing country followed by China, Thailand and Pakistan (Anon, 2006). It belongs to the genus Mangifera (Anacardiaceae) which comprises of 73 genera and about 830 species and has its origin in the northern foothills of Indian-Myanmar region (Yamanaka et al., 2006). Mango, the choicest fruit of India is rightly titled as the 'King of fruits' because of its wide adaptability, high nutritive value, richness in variety, delicious taste, excellent flavor, attractive appearance and popularity among masses. Asia is the main producer with $76.9 \%$ of the total world production, followed by America with $13.38 \%$, Africa with $9 \%$ and less than 1\% each for Europe and Oceania (Sauco, 2002). In Bangladesh, mango ranks first in terms of area and third in production. According to (FAO, 2014), Bangladesh produces 889 thousand tons of mango per annum. More than 100 varieties are grown in the country but they cover small area and mainly concentrated in Chapai Nawabganj, Rajshahi, Dinajpur, Jessore and Satkhira districts (Mannan et al., 2003). Genetic diversity available in existing germplasm determines the success of any crop improvement programme (Harlan, 1976; Moose and Mumm, 2008).

There is a considerable confusion regarding cultivar identification, because as presently several mango cultivars of many synonyms in different regions which make identification difficult. Similar cultivars grown in different areas are known by different names. For example, Banganpalli is known by different names like Baneshan, Chepta, Chaptai, Safeda etc. However, the performance of varieties is found to vary under different climatic conditions (Singh, 1978) and also different cultivars sometimes appear under the same name. So identification differentiation of cultivars through 
morphological features alone is inefficient and inaccurate. This is further compounded by the perennial nature of the crop. The morphological markers are influenced by the environmental conditions, making identification labour intensive and time consuming. Biochemical markers such as isoenzyme and protein patterns though minimally influenced by the environment offer limited polymorphism and often do not allow distinction between closely related genotypes. Many of these drawbacks of morphological and biochemical markers can be overcome through direct identification of genotypes with DNA based genetic markers. Recently reliable DNA based genetic markers have been developed and introduced for mango cultivar identification. A simple, reliable, unambiguous, fast and cost effective determination of genetic diversity in plant varieties is essential for proper varietal identification, classification, and conservation, finally helpful for plant improvement. Not only the DNA-based genetic markers are useful for varietal identification but also further estimation of genetic diversity and relatedness between mango accessions, hybrids are expected to play an important role in the future plant improvement programs.

The molecular marker i.e. RAPD, ISSR, and Microsatellite are widely used for varietal identification and genetic diversity analysis. The RAPD method has advantages over other kinds of DNA-based genetic markers; it is relatively quick, easy to perform, cheaper, highly informative, need not only prior information of template DNA sequence and synthesis of specific markers. Hence, the present study was conducted to assess genetic diversity and genetic relationships among mango germplasm/genotypes.

\section{Materials and Methods}

\subsection{Experimental location, sample collection and preparation}

Random Amplified Polymorphic DNA analysis (RAPD) of mango Germplasm was carried out during the period of August 2013 to June 2014 in the Molecular Horticulture laboratory, Agrotechnology Discipline, Khulna University, Khulna-9208, Bangladesh. In the present study, 25 mango genotypes were obtained from the south-western part of Bangladesh (Table 1). Approximately $5 \mathrm{~g}$ of recently matured and tender leaves (7-10 days old) was collected, washed using distilled water, wiped with $70 \%(\mathrm{v} / \mathrm{v})$ ethanol and then air dried, of which 1 $\mathrm{g}$ was weighed out and stored in sealed plastic bags at $-80^{\circ} \mathrm{C}$ for further use.

\subsection{DNA extraction and purification}

The DNAzol protocol which is based on the use of a novel guanidine detergent lysing solution that allows the selective precipitation of DNA from the lysate (Chomczynski et al., 1998) is fast and permits efficient isolation of genomic DNA from a variety of plant tissues that why we followed the methods of Chomczynski et al. (1998). $0.5 \mathrm{~g}$ to $1 \mathrm{~g}$ leaf samples were ground into powder with mortar and pestle and $1-1.5 \mathrm{ml}$ of DNAzol (Invitrogen, USA) was added and then homogenized properly. The mixture was centrifuged at $12,000 \mathrm{rpm}$ for 10 minutes and transferred the supernatant to another $1.5 \mathrm{ml}$ centrifuge tube. DNA was precipitated from the lysate/homogenate by the addition of $0.5-0.75 \mathrm{ml}$ of $100 \%$ ethanol and then mixed gently by inverting tubes $3-5$ times and stored at room temperature for 2-3 minutes to form

Table 1: Location wise distribution of collected germplasm of mango from south-western region of Bangladesh

\begin{tabular}{|c|c|c|c|}
\hline $\begin{array}{l}\text { Germ- } \\
\text { plasm } \\
\text { no. }\end{array}$ & Designation & NOF & $\begin{array}{c}\text { Location of } \\
\text { collection/ Address }\end{array}$ \\
\hline Gp02 & Alfazbomby & A & Germplasm center, KU \\
\hline Gp03 & Chini Lota & B & Boro Kasipur, Tala, Satkhira \\
\hline Gp17 & Local & A & Germplasm center, KU \\
\hline Gp18 & Local & A & Germplasm center, KU \\
\hline Gp28 & Prem Somudro & $\mathrm{C}$ & Dattradanga, Dumuria, Khulna \\
\hline Gp31 & Kohitur small & A & Germplasm center, KU \\
\hline Gp32 & Local & A & Germplasm center, KU \\
\hline Gp33 & Chini Dofolla & A & Germplasm center, KU \\
\hline Gp36 & Arsina & A & Germplasm center, KU \\
\hline Gp37 & Prem Thakur & $\mathrm{D}$ & $\begin{array}{l}\text { Sanasgasa, Goyrigona, } \\
\text { Kesobpur, Jessore }\end{array}$ \\
\hline Gp44 & Dasheri & A & Germplasm center, KU \\
\hline Gp50 & Vut Bombay & $\mathrm{E}$ & Arosnagor, Dumuria, Khulna \\
\hline Gp51 & Sindur Kota & $\mathrm{F}$ & Magurghona, Dumuria, Khulna \\
\hline Gp52 & Lagra & G & $\begin{array}{l}\text { Sorulia, Patkelghata, Tala, } \\
\text { Satkhira }\end{array}$ \\
\hline Gp56 & Gopale Dhopa & $\mathrm{H}$ & Payikgasa, Khulna \\
\hline Gp57 & Sojne Tule Am & $\mathrm{H}$ & Payikgasa, Khulna \\
\hline Gp61 & Apple Am & I & Moutola, Kaligong, Satkhira \\
\hline Gp68 & Lagra & A & Germplasm center, KU \\
\hline Gp69 & Surmy Fozli & A & Germplasm center, KU \\
\hline Gp70 & Local & A & Germplasm center, KU \\
\hline Gp71 & Local & A & Germplasm center, KU \\
\hline Gp73 & Hybrid-10 & A & $\begin{array}{l}\text { Germplasm } \\
\text { center, KU }\end{array}$ \\
\hline Gp75 & Amrupally & A & $\begin{array}{l}\text { Germplasm } \\
\text { center, KU }\end{array}$ \\
\hline Gp84 & Gobindo Bhog & $\mathrm{J}$ & Chougasa, Patkelghata, Satkhira \\
\hline GP87 & Kirshapate & E & Shukdebpur, Tala, Satkhira \\
\hline
\end{tabular}

NOF: Name of the farmer; A: Germplasm center; B: Mir. J. Rahman; C: C.Mondal; D: M.J.Rasul; E: M.R.Islam; F: M.S.A.Gazi; G: C. Kazi; H: Tuku; I: S.I.Ali; J: S.A.Audud; KU: Khulna University 
a well mixed homogenous solution. As DNA became visible as a cloudy precipitate and then the mixer was centrifuged at 12,000 rpm for 10 minutes again. The DNA precipitated was found and needed to discard supernatant and there after precipitated DNA was washed with $75 \%$ of ethanol about 2-3 times. After addition of ethanol, inverting the tubes 8-10 times and were stored the tubes vertically for $0.5-1$ minutes to allow the DNA to settle to the bottom of the tubes and were removed ethanol through decanting and pepeting. Finally air dried the DNA pellet.

\subsection{DNA solubilization and quantification}

The air dried pellet was dissolved in $300 \mu \mathrm{l}$ of $8 \mathrm{mM}$ $\mathrm{NaOH}$ was stored at $-20{ }^{\circ} \mathrm{C}$. The DNA was checked in 1 percent agarose gel electrophoresis and quantified using UV spectrophotometer (T $60 \mathrm{UV}-\mathrm{Visible,} \mathrm{PG} \mathrm{instrument}$ Ltd). $2 \mu \mathrm{l}$ of isolated DNA sample from each germplasm of mangoes were taken and made up to $2000 \mu \mathrm{l}$ or $2 \mathrm{ml}$ with 8 $\mathrm{mM} \mathrm{NaOH}$. The entire isolated DNA samples were quantified using UV spectrophotometer at $260 \mathrm{~nm}$ and $280 \mathrm{~nm}$. The ratio OD 260/280 should be determined to assess the purity of the sample. The concentrations of absorbance were calculated by using the following formula:

DNA concentration $\left(\mu \mathrm{g} \mathrm{ml}^{-1}\right)=\left(\mathrm{OD}_{260}\right) \times($ dilution factor $) \times(50$ $\mu \mathrm{g}$ DNA ml $\left.l^{-1}\right) /\left(100 \mathrm{OD}_{260}\right.$ unit $)$.

The DNA solution was expressed in $\mathrm{ng} \mathrm{mL}^{-1}$ (Hoisington et al., 1994). The final concentrations of mango DNA stock solutions were adjusted to $100 \mathrm{ng} \mathrm{mL}-1$ for PCR reaction.

\subsection{Selection of primer}

Primers were selected mainly based on GC content, intensity of bands, presence of smearing, consistency within individuals and potential for population discrimination. Primers that have GC content more than $60 \%$ are suitable for RAPD analysis. We selected seven subsets of primers supplied by Bioneer, South Korea (Table 2) among them seven (AL07, OPA06, OPF08, OPG17, OPO07, OPH15 and OPK14) were exhibited good quality banding patterns and sufficient variability. Annealing temperature was calculated by the following formula: $0.3 \times \mathrm{Tm}$ (primer) $+0.7 \times \mathrm{Tm}$ (product) -25 .

\subsection{PCR reaction}

PCR was carried out in My Genie 96 Thermal Block, Bioneer, South Korea. PCR amplification was preceded according to the method of (Simon et al., 2007). The PCR reaction was carried at in a final volume of $20 \mu \mathrm{l}$ reaction mixture contained PCR stock DNA $(2 \mu \mathrm{l})$, top polymerase $(2 \mu \mathrm{l})$, DNTPs $(2 \mu \mathrm{l}), 10 \mathrm{X}$ reaction buffer $(2 \mu \mathrm{l}), 5$ Pmoles primers $(1 \mu \mathrm{l})$, sterile water (11 $\mu \mathrm{l})$. The chemical was supplied by bioneer, South Kora. The Mixture was over layered with a drop of mineral oil. This reaction mixture involved in PCR amplification conditions (PCR lead at $105^{\circ} \mathrm{C}$, hot start at $94^{\circ} \mathrm{C}$ for 4 min's, denaturation at $94{ }^{\circ} \mathrm{C}$ for $1 \mathrm{~min}$, annealing at $35^{\circ} \mathrm{C}$ for $1 \mathrm{~min}$, extension at
$72{ }^{\circ} \mathrm{C}$ for 2 min's, 35 cycles, final extension at $72{ }^{\circ} \mathrm{C}$ for 05 min's, holding at $4{ }^{\circ} \mathrm{C}$ for 08 min's and end).

2.6. Electrophoresis of the amplified products and documentation

Amplified PCR products were electrophoresis (Agaro-power system) on an agarose gel (2\%) in TAE buffer and visualized by staining with ethidium bromide solution. Polymorphic band was observed by high performance UV trans-illuminator (UVP-USA) and picture was taken by the GEL DOC/BioImaging System affiliated digital camera.

\subsection{Methods of PCR product analysis}

For the study of genetic diversity, each germplasm was scored manually for presence or absence of a particular amplification product. Data were analyzed by the software GelQuest and MEGA 5.05 for phylogenic parameter. RAPD matrix of the 25 germplasm of mango using AL07, OPA06, OPF08, OPG17, OPO07, OPH15 and OPK14 primer were assembled for statistical analysis. The sizes of the fragments were estimated using DNA $1 \mathrm{~kb}$ and $100 \mathrm{bp}$ ladder by electrophoresis with the PCR products. The unweighted pair group method with arithmetic averages (UPGMA)-based dendogram was constructed using the MEGA 5.05. Numerical value was considered to construct the dendogram and presence of band (1) and absence of band ( 0 ) value were considered for these RAPD analysis.

\section{Results and Discussion}

\subsection{Genetic diversity by RAPD analysis}

Mango is the most wide spread species of the Mangifera genus. It forms forest associations with homesteads, tropical rain forests, dry evergreen forests, and the montane vegetation of mountain groups (Hossain and Nath, 1995). However, healthy, fresh 25 different Gps of young tender leaves were collected for the isolation of good quality of DNA. Matured leaves were avoided because they are rich in phenol, secondary metabolites and polysaccharides. Extraction and purification of DNA from fresh leaf tissues was done by using DNAzol protocol (Chomczynski et al., 1998). On the other hand, (Puchooa, 2004) and some other used the CTAB method of plant DNA

\begin{tabular}{lcc}
\hline \multicolumn{3}{l}{ Table 2: List of random primer } \\
\hline Primer code & Sequence (5'-3') & GC content (\%) \\
\hline AL 07 & CCGTCCATCC & $70.00 \%$ \\
OPA 06 & GGTCCCTGAC & $70.00 \%$ \\
OPF 08 & GTCCACACGG & $70.00 \%$ \\
OPG 17 & TCCCAGAGAC & $60.00 \%$ \\
OPO 07 & GAAACGGGTG & $60.00 \%$ \\
OPH15 & AATGGCGCAG & $60.00 \%$ \\
OPK 14 & CCCGCTACAC & $70.00 \%$ \\
\hline
\end{tabular}


extraction with or without modification. The quality of DNA was confirmed by $1 \%$ Agarose Gel Electrophoresis (Figure 1).

PCR is the technique of choice for nucleic acid quantification. The DNA quantity was determined by $260 \mathrm{~nm}$ and the UV spectrophotometer readings showed that the presence of DNA for the PCR stock. However, successful quantification depends crucially on the quality of the sample DNA analyzed. Whereas, (Puchooa, 2004) reported the yield of DNA g ${ }^{-1}$ of leaf tissue extracted using a UV-VIS Spectronic Genesys spectrophotometer at $260 \mathrm{~nm}$. Similarly, Katarina et al. (2006) confirmed the quality of DNA by $1 \%$ Agarose Gel Electrophoresis and DNA quantity was determined by $260 \mathrm{~nm}$ and quantified DNA was subjected to PCR amplification. Like others we quantified the purified DNA at $260 \mathrm{~nm}$ and the UV spectrophotometer readings (Table 3.) showed that the presence of DNA at high concentration and subsequently we diluted the DNA to $100 \mathrm{ng} \mathrm{mL}^{-1}$ as per requirements for ideal PCR.

The PCR was run with seven primers and among them four primers showed reproducibility. The PCR product reproducibility and banding pattern was confirmed by $1.5 \%$ and 2\% Agarose Gel Electrophoresis with $1 \mathrm{~kb}$ and 100 bp ladder. In which it was found out that the perfect and clear banding pattern revealed from 2\% Agarose Electrophoresis and most of band was similar to $100 \mathrm{bp}$ segregation ladder. This result is almost similar to others. All of the seven representative polymorphic gel profiles using the primers (AL07, OPO07, OPK14, OPH15, OPF08, OPA06 and OPG17) are shown in figure 2, 3, 4, 5, 6, 7 and 8 .

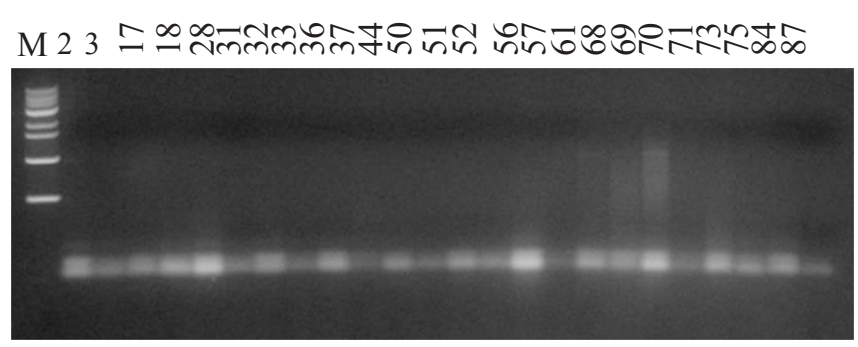

Figure 1: The gel profile of Mangifera indica DNA extraction

It is well established that RAPD technique had been successfully used in variety of taxonomic and genetic diversity studies (Rodriguez et al., 1999; Alam et al., 2009) and it was found suitable for use with Mangife indica genotype because of its ability to generate reproducible polymorphic bands. Monomorphic bands are those which are present in all individuals, polymorphic are present in one or more but not all individuals and unique ones are present in at least one individual not in any other (Mehetre et al., 2004). Indeed, we found (Table 4.) 07 unambiguous, readable and reproducible RAPD markers were produced using the seven selected primers. The number of bands obtained the average of 6.88 bands using the primers, of the 48 bands, 46 bands (95.92\%) were polymorphic and shared between in $25 \mathrm{Gp}$ while 02
Table 3: UV spectrophotometer readings at $260 \mathrm{~nm}$ showed the presence of DNA

\begin{tabular}{lclc}
\hline GP No. & $260 \mathrm{~nm}$ & GP No. & $260 \mathrm{~nm}$ \\
\hline 02 & 0.086 & 52 & 0.033 \\
03 & 0.068 & 56 & 0.038 \\
17 & 0.029 & 57 & 0.045 \\
18 & 0.021 & 61 & 0.026 \\
28 & 0.076 & 68 & 0.051 \\
31 & 0.027 & 69 & 0.023 \\
32 & 0.046 & 70 & 0.064 \\
33 & 0.041 & 71 & 0.022 \\
36 & 0.048 & 73 & 0.031 \\
37 & 0.060 & 75 & 0.061 \\
44 & 0.026 & 84 & 0.031 \\
50 & 0.025 & 87 & 0.029 \\
51 & 0.046 & & \\
\hline
\end{tabular}

bands (4.08\%) were monomorphic whereas primer AL07, OPO 07, OPK14, OPA 06 and OPG17 are more reproducible. The correlation between GC content of the primer and the number of bands could be explained as the greater hydrogen bonding: with $\mathrm{C}$ by three hydrogen bonds show the high stability of base complementation than that of complementation of $\mathrm{A}$ with $\mathrm{T}$

Table 4: Details of band produced by seven random primers in 25 mango germplasm

\begin{tabular}{lcccc}
\hline $\begin{array}{l}\text { Primer } \\
\text { code }\end{array}$ & $\begin{array}{c}\text { Total } \\
\text { no. of } \\
\text { band }\end{array}$ & $\begin{array}{c}\text { No. of } \\
\text { monomorphic } \\
\text { bands }\end{array}$ & $\begin{array}{c}\text { No. of } \\
\text { polymor- } \\
\text { phic bands }\end{array}$ & $\begin{array}{c}\text { Percent of } \\
\text { polymor- } \\
\text { phism }\end{array}$ \\
\hline AL 07 & 10 & 00 & 10 & 100.00 \\
OPO 07 & 06 & 00 & 06 & 100.00 \\
OPK 14 & 06 & 00 & 06 & 100.00 \\
OPH 15 & 07 & 01 & 06 & 85.71 \\
OPF 08 & 07 & 01 & 06 & 85.71 \\
OPA 06 & 05 & 00 & 05 & 100.00 \\
OPG 17 & 07 & 00 & 07 & 100.00 \\
Total & 48 & 02 & 46 & 95.92 \\
\hline
\end{tabular}

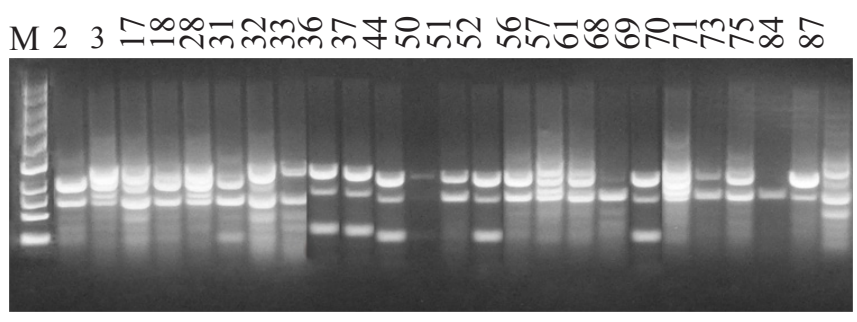

Figure 2: RAPD pattern generated by the primer AL 07, Numbers show the serial number of the genotypes and " $M$ " indicates ladder 


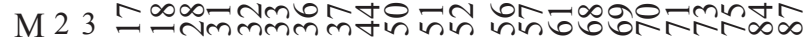

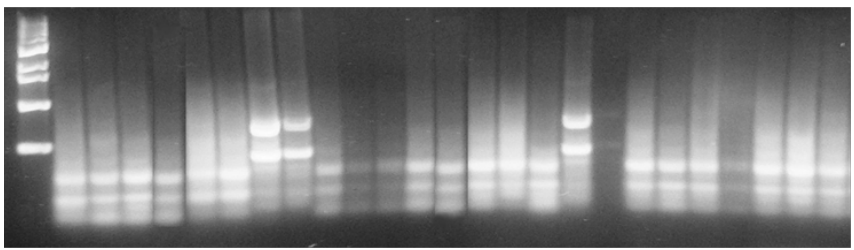

Figure 3: RAPD pattern generated by the primer OPH 15

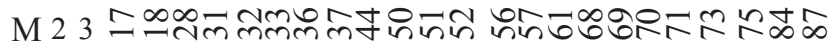

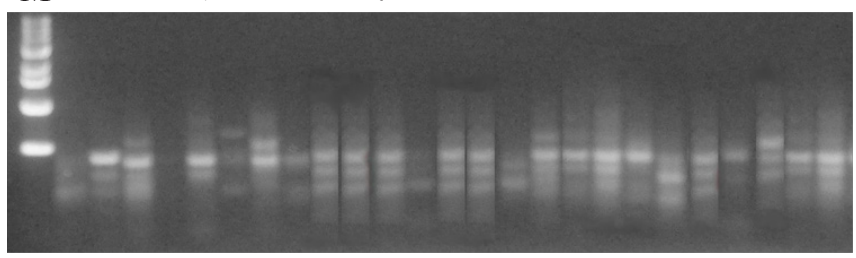

Figure 4: RAPD pattern generated by the primer OPA 06

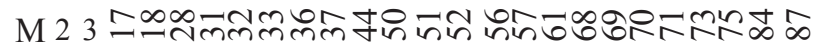

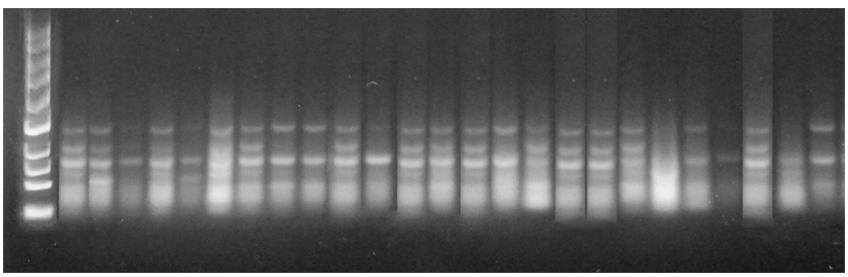

Figure 5: RAPD pattern generated by the primer OPK 14

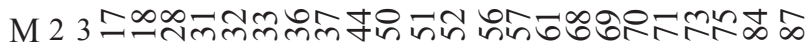

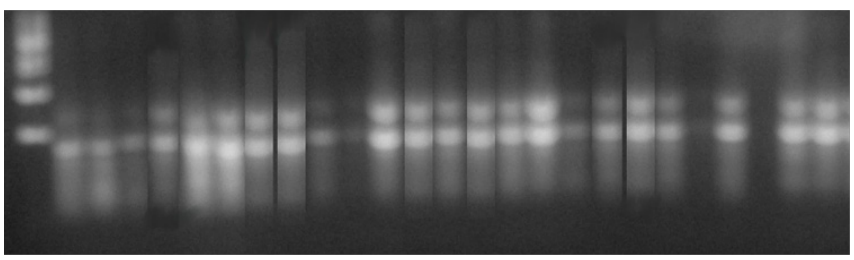

Figure 6: RAPD pattern generated by the primer OPO 07

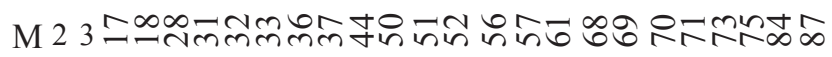

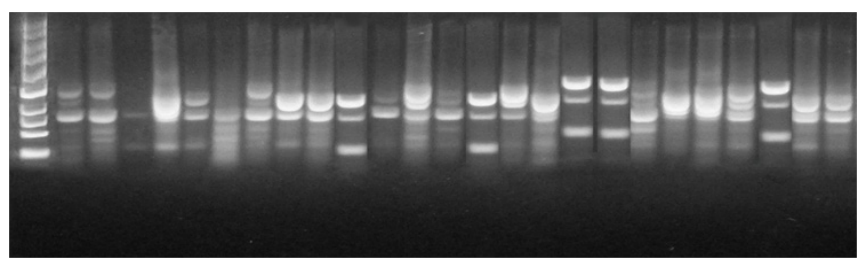

Figure 7: RAPD pattern generated by the primer OPF 08

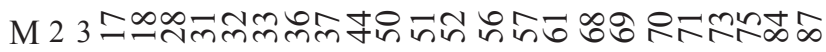

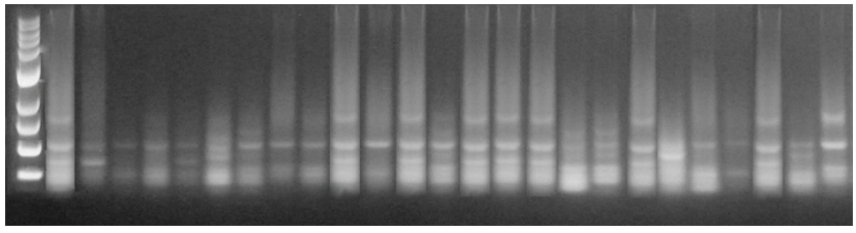

Figure 8: RAPD pattern generated by the primer OPG 17

$<$

by two hydrogen bonds (Fukuoka et al., 1992).

\subsection{Dendogram}

Twenty five genotypes on the dendrogram were distinguished and divided into two major groups as shown in Figure 09 based on (Nei's, 1979) genetic distance using Unweighted Pair Group Method of Arithmetic Means (UPGMA). UPGMA dendrogram was constructed according to the morphological data. The dendrogram (Figure 9) shows that all the germplasm were grouped into two major clusters $\mathrm{C} 1$ and $\mathrm{C} 2$. Cluster $\mathrm{C} 1$ subdivided into $\mathrm{C} 1-\mathrm{A}$ and $\mathrm{C} 1-\mathrm{B}$, Cluster $\mathrm{C} 1-\mathrm{A}$ subdivide into $\mathrm{C} 1-\mathrm{Aa}$ and $\mathrm{C} 1-\mathrm{Ab}$ and Cluster $\mathrm{C} 2$ subdivided into $\mathrm{C} 2-\mathrm{A}$ and G2-B (Figure 9).

Morphological characterization was determined and showed genetic similarities and dissimilarities by collecting data and constructing the UPGMA dendrogram to estimate the genetic diversity of mango phenotypically. From the dendrogram

$\mathrm{C} 1$

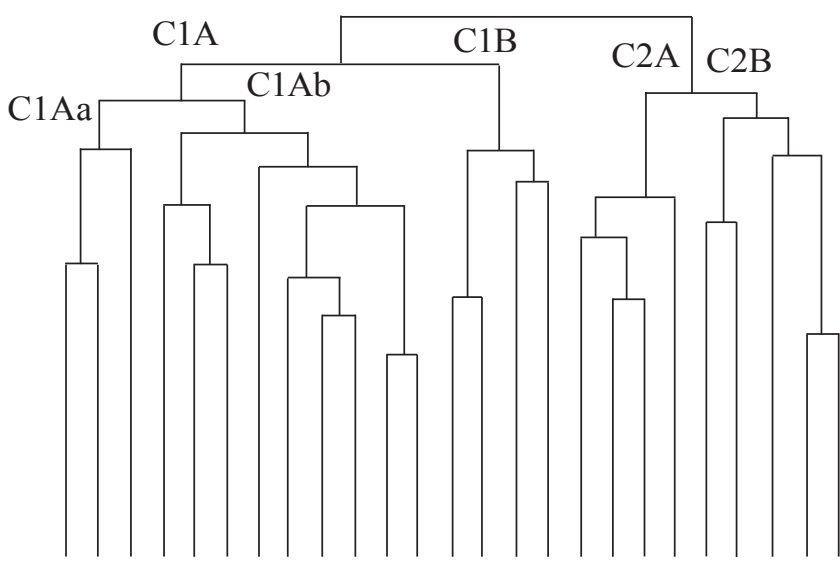

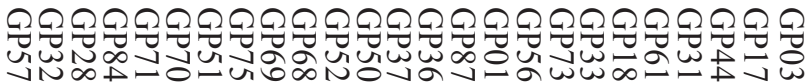

$$
\begin{array}{llllll}
\hline 0.5 & 0.4 & 0.3 & 0.2 & 0.1 & 0.0
\end{array}
$$

Figure 9: UPGMA dendrogram based on Nei's (1979) genetic distance

(Figure 9) it was found that most of the cultivated mango collected from Satkhira, Jessore and Khulna University germplasm were grouped under $\mathrm{C} 1$ and $\mathrm{C} 2$ cluster.

\subsection{Genetic distance}

DNA amplification was repeated four times. Genetic similarity matrix (Table 5) was generated using GelQuest based on the marked scores of the polymorphic RAPD patterns where score 1 or 0 was assigned to the present or absent band.

Estimates of genetic distance calculated all possible pairswise genetic distance values by the Nei's and Li's following formula:

$\mathrm{d}_{\mathrm{xy}}=1-\left\{2 \mathrm{n}_{\mathrm{xy}} /\left(\mathrm{n}_{\mathrm{x}+} \mathrm{n}_{\mathrm{y}}\right)\right\}$

Where, $n_{x}$ and $n_{y}$ are the numbers of bands amplified in individuals $\mathrm{x}$ and $\mathrm{y}$, respectively, and $2 \mathrm{n}_{\mathrm{xy}}$ is the number of 


\begin{tabular}{|c|c|c|c|c|c|c|c|c|c|c|c|c|c|c|c|}
\hline Sample & GP2 & GP3 & GP17 & GP18 & GP28 & GP31 & GP32 & GP33 & GP36 & GP37 & GP44 & GP50 & GP51 & GP52 & GP56 \\
\hline GP2 & 1.00 & & & & & & & & & & & & & & \\
\hline Gp3 & .286 & 1.00 & & & & & & & & & & & & & \\
\hline Gp17 & .276 & .250 & 1.00 & & & & & & & & & & & & \\
\hline Gp18 & .273 & .245 & .236 & 1.00 & & & & & & & & & & & \\
\hline Gp28 & .273 & .283 & .273 & .231 & 1.00 & & & & & & & & & & \\
\hline Gp31 & .200 & .282 & .200 & .231 & .231 & 1.00 & & & & & & & & & \\
\hline Gp32 & .180 & .220 & .213 & .172 & .207 & .207 & 1.00 & & & & & & & & \\
\hline Gp33 & .320 & .208 & .280 & .234 & .319 & .319 & .245 & 1.00 & & & & & & & \\
\hline Gp36 & .179 & .296 & .250 & .132 & .208 & .208 & .153 & .333 & 1.00 & & & & & & \\
\hline Gp37 & .164 & .320 & .273 & .154 & .231 & .192 & .172 & .362 & .057 & 1.00 & & & & & \\
\hline Gp44 & .236 & .245 & .200 & .231 & .232 & .320 & .172 & .362 & .170 & .154 & 1.00 & & & & \\
\hline Gp50 & .358 & .373 & .283 & .240 & .320 & .164 & .250 & .289 & .160 & .200 & .240 & 1.00 & & & \\
\hline Gp51 & .207 & .185 & .172 & .164 & .200 & .164 & .148 & .240 & .107 & .127 & .127 & .170 & 1.00 & & \\
\hline Gp52 & .309 & .358 & .273 & .269 & .345 & .308 & .241 & .362 & .170 & .192 & .192 & .043 & .127 & 1.00 & \\
\hline Gp56 & .250 & .184 & .214 & .245 & .283 & .170 & .220 & .208 & .222 & .245 & .208 & .255 & .143 & .283 & 1.00 \\
\hline Gp57 & .213 & .220 & .180 & .207 & .207 & .172 & .094 & .283 & .153 & .172 & .207 & .250 & .148 & .241 & .220 \\
\hline Gp61 & .193 & .309 & .228 & .296 & .259 & .185 & .233 & .388 & .200 & .222 & .185 & .346 & .228 & .333 & .309 \\
\hline Gp68 & .288 & .259 & .254 & .321 & .250 & .288 & .226 & .333 & .298 & .286 & .286 & .333 & .220 & .321 & .263 \\
\hline Gp69 & .276 & .321 & .276 & .200 & .309 & .273 & .246 & .360 & .214 & .200 & .200 & .245 & .238 & .164 & .214 \\
\hline Gp70 & .321 & .333 & .321 & .245 & .358 & .321 & .186 & .333 & .222 & .245 & .283 & .294 & .214 & .245 & .259 \\
\hline GP71 & .388 & .319 & .306 & .217 & .348 & .304 & .269 & .317 & .277 & .304 & .261 & .273 & .224 & .261 & .234 \\
\hline GP73 & .308 & .240 & .308 & .224 & .347 & .306 & .273 & .318 & .320 & .347 & .347 & .447 & .346 & .510 & .240 \\
\hline GP75 & .259 & .346 & .333 & .294 & .255 & .294 & .263 & .348 & .154 & .176 & .216 & .224 & .185 & .250 & .231 \\
\hline Gp-84 & .158 & .273 & .263 & .259 & .216 & .255 & .200 & .306 & .200 & .222 & .259 & .269 & .158 & .296 & .236 \\
\hline Gp-87 & .111 & .213 & .175 & .167 & .233 & .200 & .121 & .273 & .148 & .133 & .200 & .241 & .143 & .233 & .180 \\
\hline \multicolumn{16}{|c|}{ Table 5: Continue... } \\
\hline Sample & & P57 & GP & & GP68 & & GP69 & GP70 & & SP71 & GP73 & Gp7 & & Gp84 & Gp87 \\
\hline Gp57 & & .00 & & & & & & & & & & & & & \\
\hline Gp61 & & 267 & 1.0 & & & & & & & & & & & & \\
\hline Gp68 & & 194 & .27 & & 1.00 & & & & & & & & & & \\
\hline Gp69 & & 213 & .36 & & .220 & & 1.00 & & & & & & & & \\
\hline Gp70 & & 254 & .34 & & .439 & & .321 & 1.00 & & & & & & & \\
\hline GP71 & & 269 & .33 & & .360 & & .347 & .273 & & 1.00 & & & & & \\
\hline GP73 & & 345 & .33 & & .358 & & .423 & .214 & & 302 & 1.00 & & & & \\
\hline GP75 & & 263 & .32 & & .164 & & .185 & .180 & & 289 & .417 & 1.0 & & & \\
\hline Gp-84 & & 200 & .28 & & .276 & & .228 & .228 & & 292 & .373 & .17 & & 1.00 & \\
\hline Gp-87 & & 121 & .22 & & .188 & & .212 & .254 & & 296 & .269 & .220 & & .096 & 1.00 \\
\hline
\end{tabular}

bands shared by those individuals In this analysis, smaller numbers are associated with more genetically similar individuals, whereas larger numbers suggest genetically dissimilarity.

The values of pair-wise comparisons of Nei's (1979) genetic distance between 25 mango genotypes were computed from 0.043 to 0.510 (Table 5). Comparatively higher genetic distance (0.510) was found between Gp no. 52 vs. Gp no. 73. The lowest genetic distance (0.043) was found between $\mathrm{Gp}$ no. 50 and Gp no. 52 . The Gp no. 50 and Gp no. 52 cultivar 
pair was very close to each other with the highest intervarietal similarity index $(95.70 \%)$ and the lowest genetic distance (0.043). On the other hand, Gp no. 52 and Gp no. 73 pair was more distant to each other with the lowest intervarietal similarity index $(49.00 \%)$ and the highest genetic distance (0.51). This is compatible with earlier studies that reported genetic similarities of 0.61-0.95 using RAPD analysis (Kumar et al., 2001). While in another study, relatively low estimates of similarity coefficients $(0.32-0.72)$ were reported among 29 Indian cultivars (Karihaloo et al., 2003).

There was a genetic variation among the studied of mango as indicated by the proportion of polymorphic loci. Estimated genetic variation in the mango might be consistent with the fact that it is a polymorphic plant. The range of genetic distance of 25 genotypes is $0.043-0.510$ and the difference between the highest and lowest genetic distance indicated the presence of variability among the 25 genotype of mango.

\section{Conclusion}

RAPD analysis is efficient and accurate for the investigation of distribution of commercial mango or local mango. The RAPD analysis is useful in the fingerprinting of each mango sample. The geographical locations, growth altitude, and climates may contribute the polymorphic RAPD of mango trees in Bangladesh. This result is beneficial for further research on the mango functionality.Cultivars from Southwest region of Bangladesh unveiled maximum diversity and indicated the potential of RAPD markers for the identification of management of mango germplasm for breeding purposes.

\section{Acknowledgement}

Authors are grateful to the Ministry of Science and Technology (NST), Government of Bangladesh for financial support.

\section{References}

Alam, M.A., Pallavi Gulati, Aswini, K.G., Gyan, P.M., Pradeep, K.N., 2009. Assessment of genetic diversity among Podophyllum hexandrum genotypes of northwestern Himalayan region for Podophyllotoxin production. Indian Journal Biotechnology 8, 391-399.

Anon, 2006. Mango-Production and Trade Analysis - Pakistan in the Global Science, Pakistan Horticulture Development Export Board (PHDEB). Lahore, Pakistan.

Chomczynski, P., Wilfinger, W., Mackey, K.,1998. Isolation of Genomic DNA from Human, Animal, and Plant Samples with DNAzol Reagents. Biotechnology International 185-188.

FAO, 2014. From Internet FAOSTAT Database, 2014.

Fukuoka, S., Hosaka, K., Kamijima, O., 1992. Use of random amplified polymorphic DNA(RAPDs) for identification of rice accessions. Japanese Journal of Genetics 67 ,
$243-252$.

Harlan, 1976. Genetic resources in wild relatives of crops. Crop Science 16, 329-333.

Hoisington, D., Khairallah, M., Gonzalez-de-Leon, D., 1994. Laboratory Protocols: CIMMYT Applied Biotechnology Center. Second Edition, Mexico, D.F., CIMMYT.

Hossain, M.K., Nath, T.K., 1995. Artocarpus heterophyllus lam. Species descriptions 2, 308-310.

Karihaloo, J.L., Dwivedi, Y.K., Archak, S., Gaikwad, A.B., 2003. Analysis of genetic diversity of Indian mango cultivars using RAPD markers. J. Hortic. Sci. Biotechnol. 78, 285-289.

Kumar, N.V.H., Narayanaswamy, P., Prasad, D.T., Mukunda, G.K., Sondur, S.N., 2001. Estimation of genetic diversity of commercial mango (Mangifera indica L.) cultivars using RAPD markers. J. Hortic. Sci. Biotechnol. 76, 529-533.

Mannan, M.A., Siddiqa, A., Chowdhury, M.S., 2003. A study on the physico-chemical characteristic of some mango varieties in Khulna region. Thesis paper 1-47.

Mehetre, S.S., Gomes, M., Eapen, S., 2004. RAPD analysis of hybrid nature of the offspring of Gossypium hirsutum $\times G$. raimondii. Current Science 84, 24-28.

Moose Stephen, P., Mumm., 2008. Molecular plant breeding as the foundation for 21 st century crop improvement. Plant Physiology 147, 969-977.

Nei, M., Li, W.H., 1979. Mathematical model for studying genetic variation in terms of restriction endonucleases. Proceedings of the National Academy of Sciences U. S. A. 76, 5269-5273.

Puchooa, D., 2004. A simple, rapid and efficient method for the extraction of genomic DNA from lychee (Litchi chinensis Sonn.). African Journal of Biotechnology 3(4), 253-255.

Rodriguez, J.M., Berke, T., Engle, L., Nienhuis, J., 1999. Variation among and within Capsicum species revealed by RAPD markers. Theory of Applied Genetics 99, 147-156.

Sauco, V.G., 2002. Magazine of chronica Horticulture. International Society of Horticulture Science 42, 14-17.

Simon, L., Shyamalamma, S., Narayanaswamy, P., 2007. Morphological and molecular analysis of Genetic diversity in Jackfruit. Horticultural Science and Biotechnology 82(5), 764-768.

Singh, R.N., 1978. Mango. Indian Council of Agricultural Research, New Delhi, 39-55.

Souza, J. da S., Almeida, C.O., Araujo, J.L.P., Cardoso, C.E.L.. 2002. Aspectos Socio-economicos. In: Genu, P.J.C. and Pinto, A.C. de Q. (Eds.), A Cultura da Mangueira. Embrapa Informacao Tecnologica, Brasilia, 20-29.

Yamanaka, N., Hasran, M., XU, D.H., Tsunematsu, H., Idris, S., Ban, T., 2006. Genetic relationship and diversity of four Mangifera species revealed through AFLP analysis. Genetics Research of Crop Evolution 53, 949-954. 